\title{
On the Food of Young Plaice (Pleuronectes platessa).
}

$\mathrm{By}$

\author{
Andrew Scott, A.L.S.
}

(Work from the Lancashire Sea Fisheries Laboratory, Piel, Barrow-in-Furness.)

THE investigation of the food contents in the stomachs of young fishes was included in the scheme of scientific investigations drawn up and initiated by Professor Herdman for the Lancashire Sea Fisheries Committee nearly thirty years ago. The lengthy series of Annual Reports contain here and there accounts of the observations made on the stomach contents of various Pleuronectidæ captured close inshore, and the pelagic stages of other fishes caught from time to time in the plankton tow-nets. No systematic attempt has, however, been made, in connection with the investigation of the Irish Sea, to determine the food of any particular species of fish during the early part of its life history.

Other observers working in other areas, notably Dr. Marie Lebour at Plymouth, have added very much to our knowledge of the early food of young fishes. Dr. Lebour's reports, published in the Journal of the Marine Biological Association, Vols. XI and XII, deal with a very large number of larval and post-larval stages of the more important food fishes caught in the tow-nets and young fish-trawl in Plymouth Sound and beyond.

The present report gives an account of the food contained in the stomachs of young plaice (Pleuronectes platessa, Linn.) from a few days after hatching to about five months old. The samples examined in April and May were taken from the spawning pond at Port Erin, Isle of Man, where they had hatched from the pelagic eggs spawned by the adult plaice early in 1921. The later stages examined during May to August represented young plaice hatched in the open sea about the same time as those in the pond, and which had made their way close inshore. They were caught by wading with a push-net lined with mosquito netting. These inshore plaice were caught by my colleague, Mr. W. Birtwistle, on the North Wales, Cheshire, and Isle of Man coasts, and varied from $13 \mathrm{~mm}$. to $87 \mathrm{~mm}$. in length. The fish were preserved in weak formalin, and the food contents were in every case ascertained by dissecting out the alimentary canal with the help of the large Leitz dissecting microscope. The contents of the alimentary canal were well preserved, and there was no difficulty in determining them. 
The smallest fish with food taken externally was $8 \frac{1}{2} \mathrm{~mm}$. in length. The stomachs of any fish less than that size contained only unconsumed yolk. The earliest food of the plaice from the spawning pond proved to be the spores of algæ. These were found in the stomachs of $80 \%$ of one sample where external food had been consumed, but none were present in any of the stomachs of young fish over $10 \mathrm{~mm}$. in length. The spores of algæ when newly set free are very motile, and quickly make their way to where the brightest light is. Wherever there are algæ growing at the sea bottom it is pretty certain that, in the spring at least, the surface water, where the young fish are usually found, will be richly supplied with spores. There will be no shortage of food, and the post-larval stages of fishes will not have much difficulty in capturing the spores. The glass aquaria at Piel are very difficult to keep clean in the spring and early summer, owing to the growth of algæ. The water is filtered through duffel bags, and small growing plants of Ulva, etc., are kept in the aquaria to provide food for Nudibranchs. From time to time conspicuous clouds of pale green spores are to be seen on the best lighted side of the aquaria. Examined under the microscope they appear as small, oval, almost colourless, and very motile bodies, and are identical with the oval organisms found in the stomachs of the smaller sizes of post-larval plaice from the spawning pond. The feeding on spores of algæ is quickly followed by the capture of Copepoda, consisting of small Harpacticoida, such as Tigriopus fulvus, Mesochra pygmaa, Idya gracilis, etc., with an occasional Copepod and Barnacle nauplius and Podon. Although no spores were found in post-larval plaice over $10 \mathrm{~mm}$. in length, there does not appear to be any distinct demarcation in size when the little plaice begin to feed entirely on Harpacticoida. In a sample of $8 \frac{1}{2} \mathrm{~mm} .24 \%$ had fed on spores only, and $8 \%$ on Harpacticoida. At $9 \frac{1}{2} \mathrm{~mm} .80 \%$ had fed on spores and $20 \%$ on Harpacticoida. At $10 \mathrm{~mm} .76 \%$ of the stomachs contained spores only, and $24 \%$ had Harpacticoida. No stomach contents of any of the fish examined consisted of a mixture of spores and Harpacticoida. The smallest Harpacticoid found in the stomach of a young plaice $8 \frac{1}{2} \mathrm{~mm}$. long seemed almost too large and solid for such a small fish to swallow. Dr. Lebour states, "fish caught in the act of swallowing Copepoda always show the tail sticking out of the mouth, so that they are swallowed head first." In some cases they apparently pass rather rapidly through the alimentary system and reach the rectum almost undigested. In these instances the tail setæ of the Copepod were always projecting through the anus to the exterior. In fact, the Copepod seemed so perfect and apparently undigested that one would almost be justified in concluding that it had entered through the anus and not through the mouth! No diatoms were found in any of the stomachs of the larval and post-larval stages sent to me for examination. While none of my material had fed 
on diatoms, it is quite clear that they are present in the pond, at times, in sufficient numbers to form a part of the food supply of the young plaice. Professor Herdman, who examined living fish taken from the pond on April 8th, found diatoms present in the stomachs along with algal spores and exoskeletons of Copepoda. None of the stomachs of the young plaice from the pond contained any trace of Polychæta. Although none of my samples of larvæ suggested that the capture of external food began before the yolk-sac was absorbed, Professor Herdman, from his examination of living and very recently preserved material on the spot, is satisfied that the plaice larvæ begin to feed by taking in solid food through the mouth long before the yolk-sac is exhausted.

The larval and post-larval plaice from the spawning pond at Port Erin were $5 \frac{1}{2} \mathrm{~mm}$. to $11 \frac{1}{2} \mathrm{~mm}$. in length. The young plaice caught close inshore with the push-net ranged from $13 \mathrm{~mm}$. to $87 \mathrm{~mm}$. Although the difference between the largest pond example and the smallest inshore specimen only amounted to $1 \frac{1}{2} \mathrm{~mm}$. in length, there is probably a material difference in their ages. Older examples could have been obtained from the pond by prolonging the collecting. This was not thought desirable, as the shallow-water plaice would be surrounded by a more varied food supply, and there could be no real comparison.

Young plaice hatched naturally in the open sea work their way inshore and are generally found in the very shallow water early in May. They are frequently left behind in the little pools of water on the shore when the tide has gone out and can be caught with a spoon. These plaice are not completely metamorphosed, and are nearly colourless and transparent. All that can be seen of them in a shallow pool are the eyes. When they are disturbed they rise from the sand and swim in an upright position until apparently exhausted, and then settle flat on the sand again. They complete their metamorphoses, increase in size, and finally disappear from the sand and mud flats in August.* The invertebrate fauna of these sand and mud flats is rich and varied. No matter how varied the fauna be, we find that these little plaice select their food from particular groups of the invertebrata. These groups are Worms, Crustacea, Mollusca, and Tunicata. A mixed menu from these groups is not uncommon; but one finds, however, that they just as frequently limit their diet to one of these groups. It is by no means rare to find them even more than selective to one group. Individuals in a catch are found to have been feeding on one particular species, although it is quite obvious, from the examination of the stomachs of their companions, that species belonging to the same group and also to other groups were present. It does not follow that the species consumed is always abundant in the plankton where the fish

* This applies to the Morecambe Bay region. Further south the metamorphosis and offshore migration occur earlier. 
are. One may examine samples of the shallow-water plankton, and even scrapings of the mud, most carefully, and find no trace of the species which sometimes completely fills the stomach and intestines of a young plaice. The late I. C. Thompson many years ago described and figured a new species of Harpacticoid Copepod (Jonesiella hyconoe) which was, and is still, far more common in the stomachs of young pleuronectidæ than in a free state. Another point which was noted during the present investigation was the predominance of specimens of the male sex of Cumacea and Amphipoda in the stomachs. The speciographer, whose investigations are confined to the examination of plankton and bottom scrapings, usually finds the female sex is more abundant than the male sex. Sars says the Cumacea, on the whole, are "true bottom forms, though the more agile adult males of some species may be found at times swarming near the surface, especially at night."

In some samples a considerable number of the young plaice dealt with had no trace of food either in the stomach or intestine. A few contained small quantities of sand, probably derived from the broken down tubes of Pectinaria after the soft parts of the worm had been digested. The quite empty alimentary systems are difficult to explain, but there must be some solution. It is known that there is a certain amount of regurgitation of the stomach contents by more fully grown fish. Occasionally interesting invertebrata have been obtained in this way from adult plaice recently caught and transferred to our tanks. The stomachs of larval and post-larval stages are easily ruptured and the contents lost. In the metamorphosing and later stages it is probable that the unnatural violence due to capture and sudden immersion in preservative brings on regurgitation of the alimentary system.

The following are the results of the examination of the stomach contents of the various samples examined :-

\section{Platce from Port Erin Spawning Pond.}

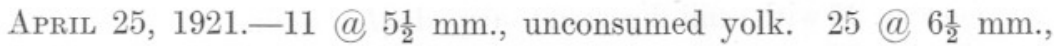
ditto. $7 @ 8 \frac{1}{2}$ mm., ditto. $35 @ 9$ mm., 31 quite empty, 1 with 1 Tigriopus, 1 with 1 Copepod nauplius, 1 with 1 Barnacle nauplius, 1 with 1 Podon. $6 @ 9 \frac{1}{2}$ mm., 3 quite empty, 2 with 1 Tigriopus each, 1 with 1 Mesochra.

APRIL 26, 1921.-25@8 @ mm., 17 quite empty, 6 with algæ spores, 2 with 1 Tigriopus each. $155 @ 9 \frac{1}{2}$ mm., 100 quite empty, 45 with algæ spores, 5 with 1 Mesochra each, 3 with 1 Tigriopus each, 2 with 1 Laophonte s'romi (male) each. $228 @ 10$ mm., 54 empty, 169 with algæ spores, 2 with 1 Amphiascus each, 2 with 1 Tigriopus each, 1 with 1 Barnacle nauplius. 
APRIL 27, 1921.-30@8 mm., all with unconsumed yolk only. 25@ $9 \frac{1}{2}$ mm., 20 with algæ spores, 1 with 3 Tigriopus, 1 with 1 Tigriopus, 1 with 1 Idycea, 1 with 1 Amphiascus, ${ }^{*} 1$ with 1 Mesochra and 1 Westwoodia.

A sample of plankton taken from the pond on this date contained a few Medusoid gonophores, a few Idyca gracitis, and 1 Crab zoea.

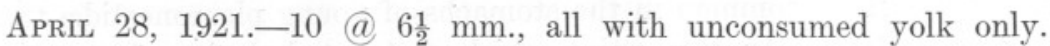
$24 @ 9 \frac{1}{2}$ mm., 23 empty, 1 with 1 Tigriopus. $28 @ 10$ mm., 14 empty, 3 with 1 Mesochra each, 1 with 3 Amphiascus, $\dagger 4$ with 1 Amphiascus $\dagger$ each, 1 with 3 Amphiascus $\dagger$ and 1 Tigriopus, 1 with 3 Amphiascus and 1 Copepod nauplius, 1 with 1 Amphiascus, 1 Mesochra, and 1 Copepod nauplius, 1 with 1 Amphiascus and 1 Copepod nauplius, 1 with 1 Wes:woodia, 1 with 1 Westwoodia, and 3 Barnacle cypris.

APRIL 30, 1921.-30@8 $\frac{1}{2}$ mm., 19 empty, 9 with algæ spores, 1 with 3 Amphiascus, 1 with 1 Idycea. $17 @ 9 \frac{1}{2}$ mm., 14 with algæ spores, 1 with 2 Amphiascus, 2 with 1 Amphiascus each, in the rectum. $27 @ 10$ mm., 17 with algæ spores, 1 with 4 Idycea, 1 with 2 Idyca, 1 with 3 Idyca, and 2 Amphiascus, 3 with 1 Idycea, and 2 Amphiascus each, 1 with 1 Idycea, 3 Amphiascus and 1 Tigriopus, 3 with 2 Tigriopus each.

MAY 4, 1921.-21@91 mm., all empty. $53 @ 10$ mm., 17 empty, 27 with algæ spores, 2 with 3 Tigriopus, 1 with 1 Tigriopus, 1 with 1 Tigriopus, 1 Mesochra and 1 Laophonte strömi (male), 1 with 2 Idycea, 1 with 1 Idyca, 1 with 2 Idycea and 1 Mesochra, 1 with 2 Mesochra, 1 with 1 Barnacle cypris. $4 @ 11$ mm., all empty.

Max 6, 1921.-20@9 @ mm., 3 empty, 14 with algæ spores, 1 with 3 Amphiascus and 1 Laophonte strömi (male), 2 with 1 Amphiascus each. $21 @ 10$ mm., 16 with algæ spores, 1 with 8 Mesochra, 2 with 1 Mesochra each, 1 with 2 Mesochra and 3 Idyce, 1 with 5 Idycea and 1 Tigriopus. 39 @11-11 $\frac{1}{2}$ mm., 1 with 10 Idycea, 1 with 15 Idyæa, and 1 Amphiascus, 1 with 12 Idyce and 1 Amphiascus, 3 with 3 Idyara each, 2 with 1 Idyca each, 2 with 1 Idyae and 1 Amphiascus each, 1 with 1 Westwoodia and 1 Amphiascus, 28 with semi-digested Copepods (Idyaa and Amphiascus) :-

\section{Plaice Caught with Push-net Lined with Mosquito Netting.}

May 6, 1921, Douglas Bay, Isle of Man.-26@15-25 mm., 12 filled with many young Pectinaria, 1 with many Pectinaria and 10 Harpacticus, 2 with many Pectinaria and 4 Harpacticus each, 1 with few Pectinaria and 18 Harpacticus, 1 with few Pectinaria and 14 Harpacticus, 1 with few

\footnotetext{
* This copepod was in the rectum with its tail seta projecting through the anus and quite undigested.

$\dagger$ In rectum as before and undigested.
} 
Pectinaria and 3 Harpacticus, 3 with few Pectinaria and 1 Harpacticus each, 1 with 3 Pectinaria and 1 Harpacticus, 1 with 3 Pectinaria, 2 Harpacticus and 1 Laophonte curticauda, 1 with 8 Pectinaria, 3 Harpacticus and 1 Longipedia, 2 with 3 Harpacticus each. $15 @ 26-35$ mm., 1 empty, 14 with many young Pectinaria. $24 @ 26-41$ mm., 1 empty, 19 with many young Pectinaria, 2 with many Pectinaria and 1 Bathyporeia (male) each, 1 with many young Pectinaria and 1 Cuma (male), 1 with many Pectinaria and 1 Pseudocuma (male). $12 @ 42-46$ mm., 8 with many young Pectinaria, 2 with many Pectinaria and 1 Bathyporeia (male) each, 1 with many young Pectinaria, 1 Bathyporeia (male) and 6 Harpacticus, 1 with 1 Perioculodes.

May 12, 1921, New Brighton Shore.-Only samples of food from stomachs sent for examination. These were filled with Temora.

May 19, 1921, Hoylake Shore.-1@21 mm., filled with Temora, but also contained 1 Calanus, 1 Centropages, and 2 Oithona. $52 @ 16-17$ mm., 3 filled with young Pectinaria only, 48 filled with Temora, and all contained one or two Calanus, Centropages and Oithona, 1 with 17 Temora, 1 Calanus, 1 Centropages, 2 Oithona and 1 Barnacle cypris.

May 20, 1921, New Brighton Shore.-71@ 15-18 mm., 34 with few young Pectinaria, many Temora, 1 or 2 Calanus, Pseudocalanus and Centropages (1 stomach contained 1 young Pectinaria, 30 Temora, 4 Calanus, 3 Pseudocalanus and 2 Centropages). 37 with many Temora, 1 or 2 Calanus, Pseudocalanus and Centropages. 4 @ 21 mm., 1 with 1 young Pectinaria, 30 Temora, 1 Calanus, 1 Cythere, 1 Barnacle nauplius and 1 Barnacle cypris. 1 with 1 young Pectinaria, 2 Temora, 2 Calanus and 1 Barnacle cypris. 1 with many Temora, and 1 Pseudocalanus, 1 with 5 Temora and 1 Calanus. 1 @ 24 mm., 90 Temora and 1 Barnacle cypris.1@30 mm., 182 Temora and 2 Pseudocalanus.

May 21, 1921. From Weir at Mouth of Ogwen River, near Bangor, N.Wales.-34@20-36 mm., 13 empty, 6 filled with young Pectinaria, 2 with few young Pectinaria, large number of Laophonte curticauda and 2 Temora, 2 with few young Pectinaria and a large number of Laophonte curticauda, 1 with few young Pectinaria, 3 Temora and 2 Laophonte, 1 with few young Pectinaria, 2 Temora, 8 Laophonte and 1 Thalestris, 1 with 3 young Pectinaria, 2 Temora and a large number of Laophonte, 1 with 1 young Pectinaria, 4 Laophonte and 1 Barnacle cypris, 5 with 2 young Pectinaria and 1 Barnacle cypris, 1 with few young Pectinaria, 2 Temora, many Laophon'e, 3 Corophium, and 3 Barnacle cypris, 1 with 3 Laophonte, 1 Thalestris and 1 Corophium.

May 29, 1921, Port Erin Bay, I.O.M.-46 @ 15-32 mm., 11 empty, 1 with few young Pectinaria and many Temora, 17 with a large number of Temora, 1 with many Temora and few Pseudocalanus, 1 with many 
Temora, few Pseudocalanus and 1 Barnacle cypris, 2 with many Temora, few Pseudocalanus and Oikopleura, 3 with many Temora, few Pseudocalanus and many Harpacticus, 2 with 8 Temora each, 1 with many Temora, many Harpacticus, 2 Jonesiella and 2 Oikopleura, 1 with many Temora, 26 Harpacticus and 2 Jonesiella, 1 with 8 Temora and 20 Oikopleura, 2 with many Temora and 1 Crab megalopa each, 1 with 12 Crab megalopa, 1 with 1 young Mysis, 1 with many Pseudocalanus, few Harpacticus, and 1 Oikopleura.

June 1, 1921, Derby Haven, I.O.M.-34 @ 17-37 mm., 8 empty, 12 filled with young Pectinaria, 3 with young Pectinaria and 8 Pseudocuma (male) each, 1 with young Pectinaria and 12 Pseudocuma (male), 2 with young Pectinaria and 1 Pseudocuma (male), 1 with young Pectinaria and 3 Diastylis (male), 1 with young Pectinaria, 1 Pseudocuma and 1 Bathyporeia, 2 with young Pectinaria and 2 Bathyporeia (male) each, 2 with young Pectinaria and a few Harpacticus, 1 with 5 Pseudocuma, 1 Idotea and 1 Bathyporeia (all males), 1 with a large number of Harpacticus (all males).

[June 1, 1921, Derby Haven, I.0.M. Flounders (P. flesus).-75 @, 16-30 mm., 9 empty, 8 filled with young Pectinaria, 52 filled with young Pectinaria and each with a few Harpacticus, 3 with young Pectinaria, a few Harpacticus and 2 Bathyporeia (male) each, 2 with young Pectinaria and a few Harpacticus and Jonesiella, 1 with a large number of Harpacticus.

June 6, 1921, Douglas Bay, I.O.M. Flounders (P. flesus).-16 @ 17-30 mm., 2 empty, 2 with many young Pectinaria, 12 with many young Pectinaria and a few Harpacticus.

June 2-6, 1921, New Brighton Shore.-70 @ 13-28 mm., 6 empty, 23 with young Pectinaria, Pseudocalanus, Temora, Centropages, Eurytemora, Acartia discaudata, Harpacticus and Barnacle cypris, 41 with Copepoda only as above.

The presence of Eurytemora and Acartia discaudata in the stomachs of this sample of young plaice indicate that the fish had been feeding in a brackish water area.

June 8, 1921, Ramsey Bay, I.O.M.-48 @ 16-35 mm., 7 empty, 15 with young Pectinaria, Ectinosoma, Jonesiella and Harpacticus, 4 with Copepoda only as above, 18 with Temora, Ectinosoma, Jonesiella, Harpacticus, and Diastylis (two stomachs had each 8 Diastylis), 3 with 1 Bathyporeia each, and 1 with 1 Synchelidium.

June 24, 1921, Hoylake Shore.-1 @ 32 mm., 1 Bathyporeia (male). $1 @ 34$ mm., many young Pectinaria. $16 @ 38$ mm., 6 filled with young Pectinaria, 2 with young Pectinaria and a few Temora and Ectinosoma, 
1 with young Pectinaria and 2 Jonesiella, 3 with 2 young Crangon each, 2 with 2 young Crangon each and a few Ectinosoma and Jonesiella, 1 with 1 Bathyporeia (male), 1 Ectinosoma, 1 Jonesiella and 1 Cythere, 1 with 1 Bathyporeia and 1 young Mytilus. $15 @ 40$ mm., 6 with young Pectinaria, 1 with Pectinaria and 1 young Crangon, 1 with Pectinaria and a few Jonesiella, 3 with 1 young Crangon each, 1 with a large number of Jonesiella, 1 with 70 Jonesiella and 8 Ectinosoma, 1 with 8 Jonesiella and 2 Ectinosoma, 1 with 2 Bathyporeia (male), 1 Cythere and 2 young Mytilus. 27 @ 42-43 mm., 7 filled with young Pectinaria, 3 with young Pectinaria, 1 Bathyporeia (male) and a few Jonesiella, 2 with Pectinaria and 1 Crab zoea each, 2 with Pectinaria and 1 Corophium each, 1 with Pectinaria, 1 young Crangon and 2 young Mytilus, 4 with Pectinaria, a few Ectinosoma and 2 young Mytilus each, 3 with 2 Bathyporeia (male) each, 1 with 1 Bathyporeia (male), 1 young Crangon and 1 Crab zoea, 3 with 1 Crangon each, 1 with 1 Crab zoea. $9 @ 45$ mm., 4 filled with young Pectinaria, 1 with Pectinaria and 1 Crangon, 2 with 3 Crab zoea each, 1 with 2 Crab zoea, 1 young Crangon, and 1 Synchelidium, 1 with 1 Bathyporeia (male). 3 @ 48 mm., all filled with young Pectinaria. 5@50-52 mm., 2 filled with young Pectinaria, 3 with Pectinaria and 1 Crab zoea each.

August 1, 1921, Port Erin Bay, I.O.M.-140@27-87 mm., 32 quite empty, 54 filled with young Pectinaria, 15 with Pectinaria and from 1-12 Eurydice, 2 with Pectinaria and a few Jonesiella, 1 with Pectinaria and a few Ectinosoma, 1 with 1 Pectinaria and a few Acartia clausi, 4 with Pectinaria and a few Ectinosoma, Jonesiella and Harpacticus, 1 with Pectinaria, 1 Bathyporeia (male) and a few Jonesiella, 3 with Pectinaria and 1 Crab megalopa each, 1 with 1 Bathyporeia (male), 1 with 1 Bathyporeia and 1 Diastylis (males), 2 with 1 Haustorius each, 2 with 1 Schistomysis each, 1 with 1 Schistomysis and 1 Eurydice, 1 with 1 Crangon, 1 with 2 Crab megalopa, 1 with 2 Diastylis (male), 1 with 3 Diastylis and a few Jonesiella, 1 filled with Temora, 1 with many Ectinosoma, 4 with Ectinosoma and a few Jonesiella and Asellopsis, 2 with Ectinosoma and a few Jonesiella, Asellopsis, and Harpacticus, 4 with Ectinosoma and a few Jonesiella, 2 with Ectinosoma and a few Harpacticus, 1 with a large number of Laophonte curticauda, 1 with a large number of Asellopsis (many males).

\section{Analyses of the Results.}

1. Plaice Hatched in the Spawning Pond at Port Erin. Total number examined $\quad . \quad$. $\quad . \quad$. $\quad . \quad 896$ Deduct larvæ with unconsumed yolk . $\quad$. $\quad$ 83 
Food.

Empty

Algal spores

Copepoda. Amphiascus minutus Claus

Idyce gracilis $\mathrm{T}$. Scott

Tigriopus fulvus Fischer

Mesochra pygmaca G. O. Sars.

Laophonte stromi Baird

Westwoodia minuta Claus

"Nauplii"

Chadocera. Podon intermedium Lillj.

Cirripedia. "Nauplius"

"Cypris"
No. of $\%$ of Stomachs. Stomachs.

. $306 \quad 37 \cdot 64$

$337 \quad 41 \cdot 45$

$57 \quad 7 \cdot 00$

$52 \quad 6 \cdot 39$

$\begin{array}{ll}23 & 2 \cdot 81\end{array}$

$18 \quad 2 \cdot 21$

$\begin{array}{ll}4 & \cdot 49\end{array}$

$\cdot 12$

$\cdot 24$

$\cdot 24$

2. Inshore Plaice Caught with Push-net.

Total number examined . . 656

Empty . . . . . . . . 79

$12 \cdot 04$

VERMES.

Pectinaria sp. .

$49 \cdot 84$

Crustacea:

Brachyura, "Zoea". . . . . . . $10-1.52$ "Megalopa". . . . . . . $7 \begin{array}{lll} & 7 & -1.06\end{array}$

Macrura, Crangon vulgaris (Linn.) . . . . $17 \quad \begin{array}{ll}17 & 2.59\end{array}$

Schizopoda, Macromysis flexuosa (Mull.) · . $\quad 1 \quad \cdot 15$

$\begin{array}{lllll}\text { Schistomysis ornata (Sars.) . } \quad 3 & & 4 & 45\end{array}$

Cumacea, Cuma scorpoides (Mont.) . . . . 115

$\begin{array}{lllll}\text { Diastylis rathkei }(\mathrm{Kr} .) & \text {. } & \text {. } & 22 & 3 \cdot 35\end{array}$

Pseudocuma cercaria (V. Ben.) . . $10 \quad 1.52$

Isopoda, Eurydice pulchra Leach . . . $16 \quad 2 \cdot 43$

$\begin{array}{lllll}\text { Idotea pelagica Leach } \quad . \quad & 1 & \cdot 15\end{array}$

Amphipoda, Bathyporeia pelagica Bate _ . $\quad 27 \quad 4 \cdot 11$

Haustorius arenarius (Slabber) . . $\quad 2 \quad \cdot 30$

Synchelidium haplocheles (Grube.) $\quad$. $2 \quad \cdot 30$

Perioculodes longimanus (B. \& W.) . $1 \quad 15$

Corophium bonellii H. M. Edw. . . $4 \quad \cdot 60$

Ostracoda, Cythere pellucida Baird . . . $3 \quad 35$ 
Copepoda (Calanoida), Food.

No. of $\%$ of

Calanus septentrionalis (H. Goodsir) . $124 \quad 18.90$

Pseudocalanus elongatus, Boeck. $\quad$. $145 \quad 22 \cdot 10$

Centropages hamatus (Lillj.) . . . $185 \quad 28 \cdot 20$

Temora longicornis (O.F.M.) . . $249 \quad 37.95$

Eurytemora affinis (Poppe) . . . $64 \quad 9 \cdot 75$

Acartia discaudata (Giesb.) _. . . $64 \quad 649 \cdot 75$

$\begin{array}{lllll}\text {, clausi Giesb. } \quad . \quad & \text {. } & 1 & \cdot 15\end{array}$

Copepoda (Cyclopoida),

Oithona similis Claus $\quad$. $\quad . \quad 50 \quad 502$

Copepoda (Harpacticoida),

$\begin{array}{llll}\text { Longipedia coronata Claus } \quad . \quad & 1 & \cdot 15\end{array}$

Ectinosoma sarsi Boeck. $\quad$. $\quad .66 \quad 66$

Thompsonula (Jonesiella) hycnce $\quad .67 \quad \begin{array}{ll}6 & 10 \cdot 21\end{array}$

(I. C. Thomp.)

Harpacticus flexus Brady. $\quad$. $\quad$. $133 \quad 20 \cdot 27$

Thalestris longimana Claus $\quad \begin{array}{llll} & \text {. } & 2 & \cdot 30\end{array}$

Laophonte curticauda Boeck. ' . . . $12 \quad 1.82$

$\begin{array}{llll}\text { Asellopsis hispida Brady. } \quad . \quad & 7 & 1 \cdot 06\end{array}$

Cirripedia, "Nauplius" . . . . . . . . 115

"Cypris" . . . . . . . . $35 \quad 353$

Mollusca.

$\begin{array}{lllll}\text { Mytilus edulis Linn. } \quad . \quad & 7 & 1 \cdot 06\end{array}$

Tunicata.

Oikopleura flabellum J. Mull. $\quad$. $\quad$. $50 \quad 55$

During the first five months of its life, the young plaice feeds almost entirely on the pelagic and semi-pelagic invertebrate living in the water through which it moves. The areas frequented by the young fish in the summer months contains a very mixed fauna. A tow-netting taken a few yards out from the shore and in not more than two feet of water usually contains truly pelagic forms, such as Calanus and Temora, along with the bottom living Cumacea, Amphipoda, etc. The young Pectinaria would very likely be captured just as they were settling into the sand at the conclusion of their pelagic life.

The results of the examination of two samples of young flounders are included to show that their food is much the same as that of the young plaice of about the same age. 